\title{
Důvodové zprávy a úmysl zákonodárce: teoreticko-empirický pohled
}

\section{Explanatory Reports and Legislator's Intention: Theoretical and Empirical Approach}

\author{
Michal Malaník*
}

\begin{abstract}
Abstrakt
Tento článek se zamèruje na približeni pojmu divvodová zpráva z teoretickébo a empirického pobledu, se speciálnim zamèrenim na koncept „úmysl zákonodárce“. Jeho cílem je pripomenout, co duivodová zpráva je, ale zejména ke čmu může slouð̌it v právni praxi (v rámci legislativního procesu a dále prì interpretaci práva soudy). Zamèruje se také na problematiku úmyslu zákonodárce, kdy upozorňuje na možná chápání, pristupy a východiska práce s timto konceptem v kontextu divvodových zpráv. Krom tohoto teoretického

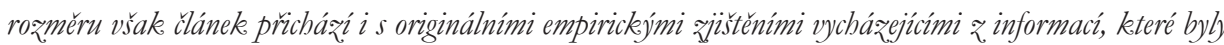
získány v rámi výzkumu tvorby práva českými legislativi. Clánek se ale neomezuje pouze na poznatky vyplývajici z. tuzemského prostredí, ale srovnává je s vybranými názory zahraničnich autori. Tento článek. tedy má potenciál obohatit povédomi o divvodových zprávách, napomoci s uchopenim konceptu „úmysl zákonodárce" a podat pomocnou ruku v otázce jejüch pochopeni na teoretické úrovni $i$ v rámci jejïch praktického vyuřití.
\end{abstract}

\section{Klíčová slova}

Dìvodová zpráva; legislativni proces; úmysl zákonodárce; empirické studie; tvorba práva; interpretace práva.

\begin{abstract}
This paper focuses on the concept of explanatory reports from a theoretical and empirical point of view, with a special focus on the concept of "legislator's intention". Its aim is to recall what an explanatory report is, but especially what it can be used for in legal practice (within the legislative process and also in the interpretation of law by courts). It also focuses on the issue of the intention of the legislator, when he draws attention to possible understandings and approaches for working with this concept in the context of explanatory reports. In addition to this theoretical dimension the paper also presents original empirical findings based on information obtained in the research of law-making with the Czech legislators. The paper is not limited to the domestic environment findings, but compares them with selected opinions of foreign authors. Thus, this article has the potential to enrich the awareness of explanatory reports, to help grasp the concept of legislator's intention, and to lend a helping hand in their understanding at the theoretical level, and in their practical use.
\end{abstract}

\section{Keywords}

Explanatory Report; Legislative Process; Intention of the Legislator; Empirical Studies; Law-making; Interpretation of Law.

JUDr. Michal Malaník, Ph.D., Katedra právní teorie, Právnická fakulta, Masarykova univerzita, Brno / Department of Legal Theory, Faculty of Law, Masaryk University, Brno, Czech Republic / E-mail: michmal@mail.muni.cz / Research ID: 57210130184 


\section{Úvod}

Tento článek se věnuje důvodovým zprávám jakožto možnému zdroji informací ohledně pracovního procesu autorů normativních textů - legislativců, kteří píšou právní předpisy. Přestože lze považovat důvodové zprávy, v širším kontextu i další dokumenty legislativní historie, za informačně hodnotné, jak bude níže ukázáno, mnozí autoři zabývající se interpretací práva je označují z hlediska jejich spolehlivosti za diskutabilní. Snahou tohoto článku je stručně objasnit nejenom to, co důvodové zprávy jsou, co se v nich může skrývat a jaký je (nebo má být) jejich obsah, ale také to, jakým způsobem o nich uvažují autoři normativního textu a následně soudci v rámci procesu interpretace práva. ${ }^{1}$

Důvodové zprávy mohou obecně sloužit k objasnění a získání hlubšího porozumění vytvářeným právním předpisům, jejichž prostřednictvím zákonodárce usiluje o regulaci společenských vztahů v určitých společenských situacích. Umožňují totiž blíže objasnit motivace navrhovatele daného normativního textu a jeho záměry. Interpretovi předmětného normativního textu pak mohou umožnit lépe navigovat cestu od psaného textu k závěrům o jeho obsahu či smyslu. ${ }^{2}$ Přestože se jedná pouze o podpůrný nástroj ke zkoumání procesu tvorby práva ${ }^{3}$, stále jsou hodné zřetele, nebot’ jsou nejčastěji vytvářeny $\mathrm{v}$ době, kdy dochází $\mathrm{k}$ samotné tvorbě právních předpisů či jiných legislativních změn a návrhů. Mohou tak být jedinečným zdrojem informací, nabízejícím interní vhled i kontext z období tvorby znění navrhovaných ustanovení.

V kontextu našeho právního prostředí jsou důvodové zprávy velmi málo probádanou oblastí. V rámci právní praxe jsou užívány jako jeden z mnoha pramenů, ze kterých lze vycházet při řešení právních prrípadů, popřípadě jako doplňkový zdroj informací při interpretaci právních textů. Stejně tak je k nim přistupováno i v rámci výzkumných projektů

1 Na tomto místě je vhodné uvést, že tento článek do značné míry navazuje na projekt GA17-149035, Metodologie empirického zjišt’ování využití interpretačních metod v tvorbě práva. Veškerá zjištění s odkazem na tuzemské legislativce byla opatřena právě v rámci tohoto výzkumu.

Nutno však také upozornit na skutečnost, že přestože $\mathrm{v}$ rámci jmenovaného projektu vznikla monografie ŠKOP, Martin, Michal MALANÍK, Terezie SMEJKALOVÁ, Markéta ŠTĚPÁNÍKOVÁ a Barbora VACKOVÁ. Tvorba práva - empirické studie. 1. vyd. Brno: Masarykova univerzita, 2019, 229 s., Acta Universitatis Brunensis Iuridica Editio Scientia. ISBN 978-80-210-9472-7, ze které i tento článek vychází, celá řada informací, které přináší tento článek, doposud prezentována nebyla, a to ani v rámci zmiňované monografie.

V tomto ohledu článek nyní upozorňuje, že s jednotlivými legislativci, kteří se projektu zúčastnili, byly prováděny hloubkové rozhovory. $\mathrm{V}$ rámci anonymizace jednotlivých osob účastných na výzkumu bude článek operovat se stejným stylem označování daných osob, jako výše zmiňovaná monografie. Pro korektní pochopení metodologie prováděného výzkumu si článek dovoluje odkázat príimo na zmiňovanou monografii, nebot' si neklade za cíl metodologii výzkumu představovat odlišně.

2 Srov ŠKOP, Martin. Některé techniky jazykové metody interpretace práva. Právník, Praha: AV ČR, Ústav státu a práva, 2017, roč. 156, č. 9, s. 4.

3 Viz kuprríkladu PECZENIK, Aleksander. A Theory of Legal Doctrine. Ratio Juris [online]. 2001, roč. 14, č. 1, s. 75-105, s. 78 [cit. 27. 12. 2020]. DOI https://doi.org/10.1111/1467-9337.00173. Dostupné z: https://onlinelibrary.wiley.com/doi/epdf/10.1111/1467-9337.00173?saml_referrer 
a odborné literatury, kdy bývá na důvodové zprávy odkazováno či s nimi operováno, nicméně bez důslednějšího metodologického uchopení. Pak zůstává otázkou, jakým způsobem bylo s danou důvodovou zprávou vlastně konkrétně nakládáno, a vzbuzuje přinejmenším pochybnosti o možné opakovatelnosti uvedených závěrů. Metodologická neprůhlednost pak činí z daných závěrů výsledky bez větší možnosti objektivizace.

Systematické zkoumání důvodových zpráv může být z hlediska jeho přínosu hodnotné jak z vědeckého, tak z praktického úhlu pohledu. Teoretické ukotvení důvodových zpráv a zjištění jejich empirických využití může osvětlit různé dílčí procesy nejen v kontextu právní interpretace, ale také tvorby právních předpisů a hodnocení jejich kvality. Takové zkoumání se však neobejde bez zvolení vhodné metody. Tento článek s odkazem na empirický výzkum zaměřený na práci tuzemských legislativcư ${ }^{4}$ nabízí několik hodnotných zjištění, která mohou napomoci pochopit úlohu důvodových zpráv v rámci jednotlivých fází existence a projevů práva. Zároveň však článek usiluje o bližší pochopení vybraných teoretických konceptů, které bývají s důvodovými zprávami spojovány, zejména pak úmyslu zákonodárce.

Přestože si tento článek neklade ambice popisovat metodologii celého provedeného empirického výzkumu, a odkazuje v tomto ohledu plně na publikaci „Tvorba práva-empirické studie" "5 považuje za vhodné objasnit alespoň kontury šetření, pro snadnější uchopení níže prezentovaných výsledků.

Cílem prováděného výzkumu bylo identifikovat a částečně objasnit jednotlivé formální i neformální faktory, které proces psaní a výslednou podobu normativního textu (právního předpisu) ovlivňují. ${ }^{6}$ Jednalo se o kvalitativní empirické šetření, které mělo sloužit primárně jako pilotní šetření, jehož účelem bylo proniknout do podstaty sociální praxe psaní právních textů. ${ }^{7}$ Jako vhodný nástroj pro dosažení vytyčeného cíle byly zvoleny a využity hloubkové rozhovory, které participantům (jednotlivým legislativcům) daly prostor jednak popsat a dále se věnovat jejich praxi - tedy procesu psaní. Ke své práci se mohli vyjádřit jak teoreticky - obecným popisováním jejich každodenních pracovních činností, tak i prakticky - aktivní práce na úpravě/interpretaci textu právního předpisu, který jim byl v rámci rozhovoru předložen. ${ }^{8}$ Jednalo se o legislativce působící různě dlouhou dobu, na různých pozicích v rámci různých orgánů státní správy. Všichni participanti ${ }^{9}$ byli lidé s právním vzděláním. ${ }^{10}$

\footnotetext{
4 Viz výše zmíněný projekt GA17-149035, Metodologie empirického zjišt'ování využití interpretačních metod v tvorbě práva.

5 ŠKOP, MALANÍK, SMEJKALOVÁ, ŠTĚPÁNÍKOVÁ, VACKOVÁ, op. cit.

6 Ibid., s. 16.

7 Ibid., s. 17.

8 Ibid., s. 17-18.

9 Celkem třináct osob, z toho osm žen a pět mužů. Dále jen: Participant/Participantka 1-13.

10 ŠKOP, MALANÍK, SMEJKALOVÁ, ŠTĚPÁNÍKOVÁ, VACKOVÁ, op. cit., s. 18.
} 
Je třeba zopakovat, že hodnota tohoto článku nespočívá v reinterpretaci výsledků empirického šetření, které jsou ve výše odkazované monografii již publikovány, ale právě ve zmínění těch, které se v rámci dané publikace neobjevily.

\section{1 Úmysl zákonodárce}

Koncept úmyslu zákonodárce je záležitostí intenzivně zkoumanou již mnoho let. V kontextu zastupitelské parlamentární demokracie, kdy je zákonodárcem instituce složená z mnoha jednotlivců, lze při jeho zkoumání spatřovat mnoho problémů. Tento článek pouze krátce shrnuje pouze některé $z$ nich, aby přiblížil nejdiskutovanější přístupy k chápání pozice a dưležitosti úmyslu zákonodárce. ${ }^{11}$

Stěžejní otázka, ke které lze najít množství různých odpovědí, je zcela fundamentální lze vůbec úmysl zákonodárce identifikovat? Existuje vůbec něco takového? Zatímco o způsobech identifikace a zdrojích úmyslu zákonodárce bude pojednáno níže, nyní se článek bude věnovat otázce jeho existence. Obhajovat existenci či neexistenci tohoto konceptu je prritom úkol značně nesnadný. ${ }^{12}$

Lze si jen těžko představit, že několik desítek či stovek osob bude mít při konstrukci normativního textu, resp. jeho přijímání, na mysli ty stejné určující okolnosti pro rozhodnutí něco upravit. ${ }^{13}$ Právě z tohoto důvodu bývá koncept úmyslu zákonodárce někdy rovnou označován jako fikce. ${ }^{14}$ Zavrhovat úvahy o úmyslu zákonodárce by bylo však pouze s odkazem na jeho nesnadnou identifikaci nesprávné. I u kolektivního tělesa lze identifikovat úmysl jednotlivců, kteří jej tvoří. Stejně pak lze pracovat s konstrukcí úmyslu celku - skupiny. Skupina jedná na základě nějakého plánu - úmyslu nějakým způsobem společně jednat. ${ }^{15}$ Tento skupinový plán nelze zpětně redukovat na úmysl jedné osoby vychází sice z dílčích úmyslů jednotlivců, nicméně dále je chápán jako plán sdílený. ${ }^{16}$

11 Pro komplexní zpracování v zahraniční literatuře viz EKINS, Richard. The Nature of Legislative Intent. Oxford University Press, 2012, 320 s. ISBN 9780199646999.

12 Shodně uvažuje již kupř́kladu HORACK, Frank Edward Jr. In the Name of Legislative Intention. Articles by Maurer Faculty [online]. 1932, s. 126 [cit. 7. 10. 2020]. Dostupné z: https://www.repository.law. indiana.edu/facpub/1196

13 RADIN, Max. Statutory interpretation. Harvard Law Review, 1930, roč. 43, č. 6, s. 870. Dostupné z: HeinOnline [právní informační systém]. DOI https://doi.org/10.2307/1330769 [cit. 27. 12. 2020].

14 Viz kupŕíkladu GREENBERG, Daniel. The Nature of Legislative Intention and Its Implications for Legislative Drafting. Statute Law Review [online]. 2006, roč. 27, č. 1, s. 24 [cit. 7. 10. 2020]. DOI https:doi. org $/ 10.1093 / \mathrm{slr} / \mathrm{hmi022}$

15 Viz kupríkladu EKINS, Richard. The Nature of Legislative Intent. Oxford University Press, 2012, s. 53.

16 EKINS, 2012, op. cit., s. 56. 
V tomto smyslu by interpreta právního textu jistě mělo zajímat, jaký kolektivní úmys ${ }^{17}$ za konkrétní podobou normativního textu stojí. Lze však uvést námitku existence předpokladu, že většina zákonodárců nečte celý text, o kterém hlasuji. ${ }^{18} \mathrm{~V}$ takovém prrípadě nemůže být řeč o kolektivním úmyslu, který vychází k konkrétních úmyslů jednotlivců, když jednotlivci nemají úmysl žádný. ${ }^{19}$ Nabízí se však jednoduchá odpověd’ - zákonodárce má vždy úmysl, který projevuje - tímto obecným úmyslem je regulovat, či neregulovat. ${ }^{20}$ Dá se též očekávat, že zákonodárce svưj úmysl projeví tím, které hodnoty a politiky se rozhodne při prijímání právního textu respektovat. ${ }^{21}$

Z pohledu interpretace normativního textu, o které ještě bude pojednáno níže, je v kontextu hledání úmyslu zákonodárce hodnotný koncept rozhovoru zákonodárce-soud. Tento koncept vychází z předpokladu, že relevantní úmysl zákonodárce je vlastně metaforou, nebot' se nedá spojit s žádným konkrétním autorem (ani členem zákonodárného orgánu, ani legislativcem, či jinými osobami, které se formálně či neformálně podílejí na právotvorbě²2). Jeho hledání je pak formou spolupráce mezi zákonodárcem a soudem. ${ }^{23}$ Snažit se zmapovat využití konceptu rozhovoru zákonodárce-soud v rámci tuzemského právního prostředí je otázkou širší případové studie, pro kterou tento

17 A je dále irelevantní, zda se tento úmysl vyskytuje, či absentuje. K tomuto blíže BELL, Bernard W. Legislative History Without Legislative Intent: The Public Justification Approach to Statutory Interpretation. Ohio State Law Journal [online]. 1999, roč. 60, č. 1, s. 54, 83 [cit. 13.1. 2021]. Dostupné z: https://core.ac.uk/download/pdf/159582552.pdf

18 POGGI, Francesca. Against the conversational model of legal interpretation. Revus [online]. 2020, č. 40, s. 7 [cit. 27. 12. 2020]. DOI https://doi.org/10.4000/revus.5694; Tento předpoklad se podařilo do značné míry potvrdit i v rámci empirického šetření týkajícího se tvorby administrativních právních předpisů na úrovni Kongresu USA. Bylo zjištěno, že v těchto př́ípadech je hlasováno o přijetí právního předpisu zejména na základě čtení doprovodných materiálů (důvodových zpráv, shrnutí...). Viz GLUCK, Abbe R. a Lisa SCHULTZ BRESSMAN. Statutory Interpretation from the Inside - An Empirical Study of Congressional Drafting, Delegation, and the Canons: Part I. Stanford Law Review [online]. 2013, roč. 65, č. 5, s. 901-1026, s. 968 [cit. 13. 1. 2021]. Dostupné z: https://digitalcommons.law.yale.edu/cgi/ viewcontent.cgi?article $=5851 \&$ context $=$ fss_papers. Není pak iracionální předpokládat, že se tak může dít i v př́padech jiných právních předpisů, i v jiných zemích.

19 POGGI, 2020, op. cit., s. 8.

20 Obdobně viz EKINS, 2012, op. cit., s. 221; Za obecný účel společného jednání zákonodárců lze považovat pripravenost regulovat pro zajištění obecného blaha.

21 Viz Viz SULLIVAN, Ruth. Sullivan on the construction of statutes. 6. vyd. Markham, Ont.: LexisNecis Canada Inc., 2014, s. 481.

22 K tomuto pojetí Paktentheorie dále viz kupř́ikladu BYDLINSKI, Franz. Základy právní metodologie. Přeložila do češtiny Jindřiška Munková. Hospodářská univerzita Vídeň [online]. 2003, s. 22-23 [cit. 27. 4. 2021]. Dostupné z: https://epub.wu.ac.at/3324/1/ap095a.pdf

23 Viz kuprríkladu ALLAN,T.R.S. Legislative Supremasy and Legislative Intention: Interpretation, Meaning, and Authority. The Cambridge Law Journal [online]. 2004, roč. 63, č. 3, s. 685-711, s. 693 [cit. 7. 10. 2020]. Dostupné z: https://www.jstor.org/stable/4509144; Že tento zejména zahraniční koncept má význam sledovat i v našem právním prostředí viz kupř́ikladu MALANÍK, Michal. Explanatory Reports as a Means to Understand the Legislator-court Dialogue. In: KLUSOŇOVÁ, Markéta, Michal MALANÍK, Monika STACHOŇOVÁ a Martin ŠKOP (eds.). Argumentation 2017: international konference on alternative methods of argumentation in law. Brno: Masarykova univerzita, 2017. 
článek neposkytuje dostatečný prostor. Jako ilustrace jeho existence lze však nahlédnout do řady rozhodnutí vrcholných soudních institucí. ${ }^{24}$

V tomto kontextu může být úmysl zákonodárce chápán jednak jako koncept účelu, který vyznačuje základní cíl daného normativního textu, ale ještě bez identifikace specifické aplikace ${ }^{25}$, a jednak jako koncept smyslu daného textu, který vyznačuje konkrétní aplikaci, která pro něj byla zamýšlena. ${ }^{26}$ Dá se však argumentovat, že k odhalení a určení účelu normativního textu není třeba hledat úmysl zákonodárce - ten je možné určit i skrze smysl textu. ${ }^{27}$ Lze tak tvrdit, že v určitém smyslu je možné označit hledání úmyslu zákonodárce za nepřesné. Nehledáme totiž úmysl zákonodárce, ale význam slov, která zákonodárce použil, a celkový smysl textu, který zákonodárce vytvořil. ${ }^{28}$

Je třeba však dále upozornit na to, že úmysl zákonodárce je záležitostí fluidní, i co se časového rámce týče. Lze totiž identifikovat několik bodů v čase, přičemž v nich nalezený úmysl může mít různou podobu i míru relevance. V relativně brzkých etapách legislativního procesu je třeba, aby se zformoval obecný souhlas na koncepci plánu, a tom, čeho jeho prostřednictvím má být dosaženo. ${ }^{29}$ Zde, skrze úmysl něco regulovat, lze formovat a identifikovat i prvotní smysl normativního textu. Tento smysl se však může díky pozdějším úpravám obsahu výsledného textu ${ }^{30}$ (ale i samotného plánu v kontextu dalších debat ${ }^{31}$ ) změnit. V momentu přijetí je však rozumné předpokládat, že zákonodárci nalezli shodu a vyjadřují tak kolektivní úmysl zákonodárného tělesa, přestože někteří z nich mohou stále o obsahu textu, dokonce i celého plánu, pochybovat. ${ }^{32}$

24 Lze zmínit kupř́kladu usnesení sociálně-správního kolegia Nejvyššího správního soudu ze dne 2. 2. 2005, č. j. S 3401/2004-62. Nejvy šš́ správní soud [online]. NSS, 2005 [cit. 27. 4. 2021]. Dostupné z: http://www. nssoud.cz/dokumenty/0092EJ_2005.pdf; V jeho rámci Nejvyšší správní soud vyslovuje názor o přípustnosti subjektivně-historického výkladu (tedy výkladu zaměřeného na úmysl zákonodárce zjišt'ovaný skrze důvodové zprávy) v prrípadech, kdy jazykový a teleologický výklad nedává jednoznačnou odpověd’ Důvodové zprávy potom nazývá důležitým zdrojem informací (byt’ bez normativní hodnoty).

Dále lze zmínit argumentačně bohatý nález Ústavního soudu ze dne 29. 5. 2013, sp. zn. Pl. ÚS 10/13, N 96/69 SbNU 465. Ústavní soud [online]. Ústavní soud, 2013 [cit. 27. 4. 2021]. Dostupné z: http:// nalus. usoud.cz/Search/GetText.aspx?sz=pl-10-13_4, kde Ústavní soud výslovně zmiňuje prvky komunikace se zákonodárcem. Zřetelné jsou tyto prvky zejména v odstavcích 104-107 nálezu s odkazem na vlastní předchozí judikaturu, kde upozorňuje na to, jaké má zákonodárce povinnosti ve vztahu k přijetí restitučního zákona. Také na mnoha místech nálezu diskutuje úmysl zákonodárce, který hledá skrze důvodové zprávy $\mathrm{k}$ diskutovaným předpisům.

25 Viz COX, Archibald. Judge Learned Hand and the Interpretation of Statutes. Harvard Law Review [online]. 1947, roč. 60, č. 3, s 370 [cit. 7. 10. 2020]. Dostupné z: https://www.jstor.org/stable/1335326

26 Viz Ibid., s. 371.

27 Viz kupŕíkladu FRENCH, Robert. The Principle of Legality and Legislative Intention. Statute Law Review [online]. 2019, roč. 40, č. 1, s. 50 [cit. 7. 10. 2020]. DOI https/doi.org/10.1093/slr/hmy031

28 Obdobně též GREENBERG, 2006, op. cit., s. 18.

29 Viz kupř́kladu GOLDSWORTHY, Jeffrey. Legislative Intention Vindicated? Oxford Journal of Legal Studies [online]. 2013, roč. 33, č. 4, s. 832 [cit. 7. 10. 2020]. Dostupné z: https://www.jstor.org/stable/24562802

30 Viz kuprríkladu EKINS, 2012, op. cit., s. 235.

31 Viz kupř́kladu GOLDSWORTHY, op. cit., s. 832.

32 GOLDSWORTHY, op. cit., s. 832. 
Objevují se však i názory, že najít konkrétní úmysl zákonodárce je z praktického hlediska nemožné, nebot' i za předpokladu, že se všichni jednotlivci kolektivního tělesa shodli na potřebě regulace s danou specifickou formulací normativního textu, je myslitelné nepřeberné množství pohnutek, které $\mathrm{k}$ tomuto aktu vedly. Je také prakticky nemožné je zjistit, a i kdyby se to podařilo, tyto informace ${ }^{33}$ by stále postrádaly normativní hodnotu. ${ }^{34}$ Normativní hodnota však není to jediné, proč by interprety mohlo lákat (a proč je láká35) zkoumat důvodové zprávy. Tyto materiály legislativní historie mají totiž ještě tzv. pravdivostní hodnotu ${ }^{36}$, tedy můžou sloužit jako důkazní prostředek o existenci konkrétních úmyslů zákonodárce a mohou vést $\mathrm{k}$ odhalení nejlepšího řešení ${ }^{37}$ vyvstalého interpretačního problému. Zcela zavrhovat existenci úmyslu zákonodárce pouze na základě většího množství pohledů na možný charakter tohoto konceptu tedy hraničí s ignorantstvím.

\section{K důvodovým zprávám a jejich interpretaci v kontextu úmyslu zákonodárce}

Tento článek předkládá kritiku myšlenek odmítajících existenci úmyslu zákonodárce v moderních systémech zastupitelské demokracie, kdy je v centru pozornosti při jeho hledání kolektivní zákonodárný orgán. Přesto je třeba přisvědčit obavám o jeho nesnadnou identifikaci skrze různé zdroje a od nich se odvijející normativní hodnotu diskutovaného konceptu. I tomuto tématu se věnuje nepřeberné množství odborných textů. Tento článek se bude soustředit téměř výhradně na jeden konkrétní zdroj - důvodové zprávy.

Je relativně zřejmé, že důvodové zprávy, které jsou součástí materiálů doprovázejících normativní text ještě před jeho schvalováním ${ }^{38}$, nejsou právně závazné a mohou interpretovi sloužit pouze jako zdroj vysvětlující záměr tvůrce normativního textu. ${ }^{39}$ Lze je tak považovat za formu pokusu mít alespoň nějaký vliv na později schválený

33 Navíc se objevují názory, že by mohlo jít spíše o dezinformace. Viz kupř́ikladu MANNING, John F. Textualism as a Nondelegation Doctrine. Columbia Law Review, 1997, roč. 97, č. 3, s. 687. Dostupné z: HeinOnline [právní informační systém]. DOI https://doi.org/10.2307/1123360 [cit. 27. 12. 2020].

34 Viz kupř́kladu obdobně RADIN, 1930, op. cit., s. 870/871.

35 Viz ESKRIDGE, William N. Jr. Legislative history values. CHICAGO-KENT LAW REVIEW, 1990, roč. 66, č. 365, s. 369/370. Dostupné z: HeinOnline [právní informační systém]. [cit. 27. 12. 2020].

36 Ibid., s. 367, 418.

37 Viz Ibid., s. 367.

38 Mezi které může zejména patřit krom důvodové zprávy i paragrafové znění s vyznačením změn, rozdílové tabulky, srovnávací tabulky (v prípadě, že se úprava dotýká problematiky upravené evropskými předpisy), tabulky s vypořádáním připomínek, obálky, usnesení, předkládací zpráva, průvodní dopisy, RIA. Kupř́ikladu Participant č. 1 a Participantka č. 8 se k této otázce vyjadřují a jmenují výše uvedené materiály.

39 Zatímco právní předpis je vyjádřen v přijatém textu, důvodové zprávy jsou pouhým odkazem na existenci právního předpisu. Viz RODRÍGUEZ, J. L. Norms, Truth, and Legal Statements. In: BELTRÁN, J. F., J. J. MORESO a D. M. PAPAYANNIS. Neutrality and Theory of Law. London: Springer Science \& Business Media, 2013, s. 129. 
normativní text. ${ }^{40}$ Mưže se však také ukázat, že důvodové zprávy mohou přinést více nesrovnalostí, než by měly objasnit, na což tento článek výslovně upozoňuje. A protože „právni argumentace má interpretativnípovahu, právo je interpretace "41 , k čemuž lze přpojit př̀edpoklad Ronalda Dworkina, že právní interpretace je podobná interpretaci umělecké ${ }^{42}$, nakládání s důvodovými zprávami je také důležitým tématem pro právní argumentaci. Důvodové zprávy jsou soudy často považovány za záložní zdroj argumentů, kterými soudci pomáhajî odůvodnit svá konečná rozhodnutí. ${ }^{43}$ Je však vhodné upozornit na skutečnost, že četnost využívání důvodových zpráv v rámci interpretace právních textů soudy nebyla nikdy testována, a tedy není možné tvrzení uvedené v předchozí větě kvantifikovat. ${ }^{44}$

Dle \ 86 odst. 3 zákona č. 90/1995 Sb., o jednacím řádu Poslanecké sněmovny, ve znění pozdějších předpisů, je důvodová zpráva povinnou součástí navrhovaného zákona ${ }^{45}$. Jejím úkolem je odůvodňovat principy nové právní úpravy, zhodnotit aktuální právní stav, vysvětlit nezbytnost úpravy nové a uvést předpokládané dopady zejména právní a hospodářské povahy, jako je soulad s ústavním pořádkem, či nároky na veřejné rozpočty. ${ }^{46}$ Kupř́ikladu dle Jana Wintra by důvodové zprávy tedy mohly být považovány za první dostupný zdroj znalostí o záměru zákonodárce. ${ }^{47}$

40 Obdobně uvažuje kupř́ikladu i Radim Boháč. Viz BOHÁČ, Radim a kol. Legislativní proces (teorie a praxe). Tiskárna Ministerstva vnitra, s. p. o., 2011, s. 324; Avšak srov. ECO, Umberto. Interpretation and Overinterpretation: World, History, Texts; The Tanner Lectures on Human Values [online]. Cambrigde University, 1990, s. 160 [cit. 29. 9. 2020]. Dostupné z: http://tannerlectures.utah.edu/_documents/a-to-z/e/ Eco_91.pdf: „Jakmile je text osvobozen od autora, existuje dále ve vakun potenciálně nekonečného počtu interpretací." [překlad aut.]; a také ŠKOP, Martin. Právo a vášeň. Jazyk, príběh, interpretace. Brno: Masarykova univerzita, 2011, s. 71: ,Jakmile je cokoli vyřčno, ztrácíme nad tím moc a nelze nikomu, ke komu se sdèlení dostane, zabránit, aby do něj nevkládal své vlastni obrazy a vize. "; Zatímco zákonodárce má vždy jasný úmysl - regulovat, nevyhnutelně ztrácí kontrolu nad následnými interpretacemi svých textů.

41 NERHOT, Patrick. Interpretation in Legal Science. In: NERHOT, Patrick. Law, Interpretation and Reality. Essays in Epistemology, Hermeneutics and Jurisprudence. Dordrecht/Boston/London: Kluwer Academic Publishers, 1990, s. 200.

42 DWORKIN, Ronald. Law's Empire. The Belknap Press of Harvard University Press, 1986, s. 51.

43 Argumentace soudců musí být přesvědčivá a důvěryhodná. Viz také NERHOT, Patrick. Interpretation in Legal Science. In: NERHOT, 1990, op. cit., s. 202; nebo CZARNEZKI, Jason J. a William K. FORD. The Phantom Philosophy? An Empirical Investigation of Legal Interpretation (September 2006). Maryland Law Review [online]. 2006, roč. 65, č. 3, čl. 4, s. 865 [cit. 28. 8. 2019]. Dostupné z: https://ssrn. com/abstract $=773865$; Ke splnění tohoto předpokladu může přispět právě i snaha odkázat na úmysl tvůrce interpretovaného právního textu.

44 Viz kupř́kladu MALANÍK, Michal. Explanatory Reports as a Means to Understand the Legislator-court Dialogue. In: KLUSOŇOVÁ, MALANÍK, STACHOŇOVÁ, ŠKOP, 2017, op. cit.

45 Viz zákon č. 90/1995 Sb., o jednacím řádu Poslanecké sněmovny, ve znění pozdějších předpisů. Poslanecká sněmovna Parlamentu Ceské republiky [online]. [cit. 21. 3. 2020]. Dostupné z: https://www.psp.cz/sqw/ sbirka.sqw? cz=90\&r=1995

46 Viz blíže $\int 86$ odst. 3 zákona č. 90/1995 Sb., o jednacím řádu Poslanecké sněmovny, ve znění pozdějších předpisů. Poslanecká snémovna Parlamentu Ceské republiky [online]. [cit. 21. 3. 2020]. Dostupné z: https:// www.psp.cz/sqw/sbirka.sqw?cz=90\&r=1995

47 Viz WINTR, Jan. Metody a zásady interpretace práva. Auditorium. Praha, 2013, s. 102. 
Pokus o odhalení úmyslu zákonodárce může být jedním z hlavních důvodů, proč vůbec důvodové zprávy analyzovat. Touto úvahou se však nevyhnutelně dostáváme mimo hranice zkoumání činností legislativců a vstupujeme do oblasti teorií právní intepretace. Článek se proto nyní pokusí krátce ožrejmit vybrané způsoby, jakými může být na projevovaný úmysl zákonodárce pohlíženo, jak co se týče jeho forem, tak jde-li o jeho význam pro pozdější interpretační výstupy. Přitom bude mít pořád v hledáčku zejména důvodové zprávy, nikoli kupř́kladu legální definice. O těch např́klad Franz Bydlinski tvrdí, že jejich pomocí se zákonodárce snaží upřesnit pojmy aplikovaných norem. Zároveň však uvádí, že takové počiny mohou vyvolávat vlastní výkladové otázky, což je také důvodem, proč nejsou při interpretaci př́liš ku pomoci. ${ }^{48}$

$\mathrm{V}$ rámci výkladových teorií v kontextu zkoumání důvodových zpráv lze upozornit zejména na historický, potažmo intencionalistický (resp. originalistický ${ }^{49}$ ) výklad práva a dále základní principy textualistického př́stupu k výkladu právních textů.

V rámci historického výkladu se snažíme na výkladovou otázku hledat odpověd' samotného zákonodárce. ${ }^{50}$ Jan Wintr tvrdí, že směrování jednotlivých výkladových prvků lze vyjádřit normativními větami, a $\mathrm{k}$ historickému výkladu tato věta může znít: „zákonnému ustanoveni prikládej význam, jaký plyne z jasnébo úmyslu zákonodárce. "51 $\mathrm{Na}$ tomto místě je však vhodné uvést, že jakkoliv je pátrání po původní myšlence stojící za existencí textu i jeho konkrétním zněním důležité, může být v mnoha ohledech zavádějící. Interpret při jeho posuzování musí akcentovat i zcela neprávní aspekty (všechny historické souvislosti, které mohly autora ovlivnit). Dále zde stále přetrvává obava, na kterou upozorňuje Dworkin - právníci často musí uznat, že v mnoha otázkách neměl autor žádný úmysl, a tedy nemůže být žádný objeven. ${ }^{52} \mathrm{~V}$ takovém prípadě je snaha interpreta nejen marná, ale navíc nutně směřje $\mathrm{k}$ nesprávnému výsledku. Tento argument je sdílen i dalšími autory: již Hans Kelsen tvrdil, že u státních zákonodárných orgánů nelze hovořit o tom, že „zamýšlely“ konkrétní obsah textů, které prìijímají. V mnoha prrípadech totiž mají jen pramalé znalosti daných prijímaných zákonů, nebot' pouze členové příslušných legislativních odborů jsou obeznámeni se všemi detaily. ${ }^{53}$

48 BYDLINSKI, 2003, op. cit., s. 12.

49 Kupř́kladu Jack Balkin jej představuje jako směr zaměřující se jak na původní smysl textu, tak na uvažování o plánu originální zamýšlené aplikace. Viz BALKIN, Jack M. Living Originalism. Cambridge, London: The Belknap Press of Harvard University Press, 2011, s. 36.

50 MELZER, Filip. Metodologie nalézání práva. Brno: Knihovnička, 2008, s. 87.

51 WINTR, 2013, op. cit., s. 27.

52 DWORKIN, Ronald. Law as Interpretation. Texas Law Review [online]. 1982, roč. 60, č. 60, s. 529 [cit. 31. 8. 2019]. Dostupné z: https://pdfs.semanticscholar.org/6a14/60d10b4fdd662c62f15130e375b8382c9803.pdf

53 Cit dle PAULSON, Stanley L. Kelsen on legal interpretation. Legal Studies, 1990, č. 136, s. $142-143$. Dostupné z: HeinOnline [právní informační systém]. DOI https://doi.org/10.1111/j.1748-121X.1990. tb00596.x [cit. 25. 1. 2018]. 
Výše zmíněnou námitkou se přesouváme k výkladovému směru, který je pro účely této části článku představen jako protipól intencionalistických myšlenek ${ }^{54}$, tedy textualismu. Pro jeho stručné představení dobře poslouží známá poučka, že ze zákona, který má být vyložen, nelze čerpat více než v něm je. ${ }^{55}$ Jelikož v rámci textualismu není prostor pro hledání úmyslů tvůrce normativního textu, které nejsou obsaženy př́mo v něm, je nezbytně nutné korektně analyzovat význam užitých slov. Není zde však ani prostor pro hledání účelů daného textu - prí úvahách o účelu textu je odkazováno též na účel, který pro něj zamýšlel jeho tvůrce. ${ }^{56}$ Antonin Scalia prútom tvrdí, že slova nemají vlastní vnitřní význam. Jejich význam je jim přisuzován dle toho, jak daný pojem interpretační komunita chápala v době jeho zavedení. Ve svém celém kontextu pak znamenají to, co dle rozumných lidí znamenala $\mathrm{v}$ době, kdy byla napsána - s vědomím, že obecné pojmy mohou obsáhnout pozdější technologické inovace. ${ }^{57}$ To však stále neznamená možnost hledat výkladové prostředky (včetně úmyslu zákonodárce) mimo text interpretovaného právního textu.

Je nasnadě uvažovat o neurčitém počtu případů, kdy budou dva výše uvedené výkladové př́stupy přinášet zcela odlišné interpretační výstupy. Jako př́klad takové situace, kdy interpretace dle textu a v něm užitých pojmů, oproti interpretaci dle úmyslu zákonodárce vysvětleného v důvodové zprávě, přináší naprosto odlišné výsledky, mưže sloužit případ novelizačního předpisu - zákona č. 277/2019 Sb., kterým se mění některé zákony v souvislosti s prijietím zákona o Sbírce zákonů a mezinárodních smluv ${ }^{58}$. Jak již upozorňují Michal Malaník a Klára Malaníková59, přechodné ustanovení zmiňovaného novelizačního předpisu ${ }^{60}$ lze označit přinejmenším za nejasné. Textualistickým výkladem by bylo možné dojít k závěru, že zákonodárce hovoří o předložení předpisu redakci Sbírky zákonů (nebot' Poslanecké sněmovně či jinému př́slušnému orgánu se nepředkládá

54 I když obecně tak být považován nemůže.

55 Viz kupř́kladu BYDLINSKI, 2003, op. cit., s. 11.

56 Viz kuprríkladu SALES, Philip. Legislative Intention, Interpretation, and the Principle of Legality. Statute Law Review [online]. 2019, roč. 40, č. 1, s. 60 [cit. 7. 10. 2020]. DOI https://doi.org/10.1093/slr/hmy025; Tomuto tvrzení však lze úspěšně kontrovat, že zatímco úmysl zákonodárce je pojem převážně subjektivistického rázu, hledání objektivního účelu právního předpisu již nikoli.

57 SCALIA, Antonin a Bryan A. GARNER. Reading Law. Thomson/West, 2012, s. xxv, 16.

58 Zákon č. 277/2019 Sb., kterým se mění některé zákony v souvislosti s přijetím zákona o Sbírce zákonů a mezinárodních smluv. Poslanecké snèmovna Parlamentu Ceské republiky [online]. [cit. 21. 3. 2020]. Dostupné z: https://www.psp.cz/sqw/sbirka.sqw?cz=277\&r=2019

59 MALANÍK, Michal a Klára MALANÍKOVÁ. Vacation legis - nenápadná změna tuzemského folklóru. Casopis pro právní védu a praxi. Brno: Masarykova univerzita, 2020, roč. 27, č. 3/2020, s. 415-428. ISSN 1210-9126. DOI. https://doi.org/10.5817/CPVP2020-3-6

60 „Upráuních predpisu vyblašovaných ve Sbírce quákonü, které byly predloženy prede dnem nabytí úcinnosti tohoto zákona a budou vyblášeny ve Sbirce zákonu po nabytí účinnosti tohoto zákona, se postupuje podle zákona č. 309/1999 Sb., ve znèni účinném do dne nabytí účinnosti tohoto zákona." Zákon č. 277/2019 Sb., kterým se mění některé zákony v souvislosti s přijetím zákona o Sbírce zákonů a mezinárodních smluv. Poslanecká sněmovna Parlamentu Ceské republiky [online]. [cit. 21. 03. 2020]. Dostupné z: https://www.psp.cz/sqw/sbirka. sqw?cz $=277 \& \mathrm{r}=2019$ 
právní předpis, ale návrh právního předpisu). Přechodné období by bylo tedy relativně krátké. Intencionalistickým výkladem s odkazem na odůvodnění pozměňovacího návrhu ${ }^{61}$, který za zněním přechodného ustanovení stojí, však lze dospět k závěru, že zákonodárce měl v úmyslu operovat s předložením návrhu právního předpisu, přestože text normativního textu tento úmysl nereflektuje. Upřednostněním intencionalistického výkladu se v tomto prŕpadě nejen markantně prodlužuje přechodné období (na blíže neurčenou dobu), ale také se od tohoto rozhodnutí odvijí den, od kterého některé právní předpisy nabývají účinnosti. Jako př́klad lze uvést odbornou veřejností diskutovaný zákon č. 39/2020 Sb., o realitním zprostředkováníi ${ }^{62}$ u kterého lze takto uvažovat o dvou dnech nabytí účinnosti v závislosti na zvoleném výkladovém směru (textualismus: 1. 7. 2020; a intencionalismus: 3. 3. 2020).

Důvodové zprávy jsou obvykle chápány toliko jako nezávazné vodítko osvětlující vůli zákonodárce. V kontextu výše uvedeného je poměrně zajímavé sledovat, že ve výše nadneseném př́padě dává odborná veřejnost většinou přednost intencionalistickému výkladu, dle odůvodnění pozměňovacího návrhu ${ }^{63}$. Tento fakt dokládají i velké právnické databáze, které s ním v souladu uvádějí datum účinnosti zákona o realitním zprostředkování ke dni 3. 3. 2020. ${ }^{64}$ Nedokonalá legislativní technika a formulace textu právního předpisu tak konstituuje výkladový problém, u něhož je myslitelné, že tuto kolizi možných výkladů rozhodne až soud.

Článek považuje za vhodné upozornit, že opomíjet důležitost důvodových zpráv je tedy i v kontextu současné právní praxe krajně nemoudré, i přes absenci jejich normativního rozměru. Úmysl zákonodárce může být v některých př́ipadech upřednostněn i tehdy, kdy je v rozporu s významem použitých termínů normativního textu.

Výše uvedené, jakkoli se jedná o př́klad vyvolávající diskuse, však také zcela neodpovídá na otázku, co je vlastně obsahem pojmu „úmysl zákonodárce“ - pouze ukazuje na jeden konkrétní problém při využití jednoho z možných pohledů.

\section{3 Úmysl zákonodárce pohledem samotného zákonodárce}

Přes výše naznačené nesrovnalosti ohledně využitelnosti (a korektnosti využitî) úmyslu tvưrce textu pro jeho následnou interpretaci je však zřejmé, že právní prostředí směruje

61 Pozměňovací návrh. Dostupný jako součást sněmovního tisku 256. Poslanecké snèmovna Parlamentu České republiky [online]. [cit. 21. 3. 2020]. Dostupné z: https://www.psp.cz/sqw/historie.sqw?o=8\&t=256

62 Viz zákon č. 39/2020 Sb., o realitním zprostředkování. Poslanecká snèmovna Parlamentu Céské republiky [online]. [cit. 21. 3. 2020]. Dostupné z: https://www.psp.cz/sqw/historie.sqw?o=8\&t=391

$63 \mathrm{Na}$ tomto místě je vhodné znovu zdůraznit, že ve vybraném prípadě jde opravdu pouze o odůvodnění pozměňovacího návrhu, nikoli klasickou důvodovou zprávu. Bylo by tedy možné otevřít otázku o povaze takovýchto odůvodnění. Pro účely tohoto článku však tuto otázku opomiňme.

64 Viz kupříkladu ASPI [právní informační systém], Beck-online [právní informační systém], Zákony pro lidi: https://www.zakonyprolidi.cz/cs/2020-39. Vše [cit. 7.10. 2020]. 
v posledních letech $\mathrm{k}$ větší akcentaci ostatních výkladových směrů než pouze textualismu. Jako zářný př́iklad může posloužit interpretační instrukce zákona č. 89/2012 Sb., občanského zákoníku, ve znění pozdějších předpisů. Ustanovení $\int 2$ odst. 2 říká prrímo:

„(2) Zákonnému ustanoveni nelze prikládat jimý význam, nežjaký plyne z vlastního smyslu slov v jejich vájemné souvislosti a zjasnébo úmyslu zákonodárce; nikdo se však nesmi dovolávat slov právního predpisu proti jeho smyslu."65

$\mathrm{Na}$ tomto ustanovení je problematická celá řada záležitostí6 ${ }^{6}$, nicméně lze odhadnout, že jeho smyslem má být zdưraznění důležitosti úmyslu zákonodárce a účelu právní úpravy. Obojí lze alespoň částečně odvodit z důvodové zprávy k předmětnému právnímu předpisu. Na druhou stranu lze uvést Scaliovu instrukci, že žádnému slovu či větě by neměl být přisuzován význam, který ve skutečnosti nenese (což je textualistická maxima „př́ípustného významu“"). ${ }^{67}$

Pokud bychom v tomto konkrétním př́padě pátrali po úmyslu zákonodárce skrze důvodovou zprávu k občanskému zákoníku, zjistili bychom, že intencionalismus nebyl autory př́liš dobře pochopen. K výkladu \ 2 uvádí důvodová zpráva následující:

„[...] zákonným ustanovením nelze prikeládat jiný smysl, nežjaký odpovídá jejich slovìm a jasnému (to jest žrejmému, jasně projevenému a z textu zákona interpretací odvoditelnému) zákonodárcové úmyslu. "68

$\mathrm{Na}$ tomto vyjádření je problematické zejména to, že pokud by byl úmysl zákonodárce zřejmý a jasně projevený, nebylo by po něm třeba pátrat. Dále je zde vhodné upozornit na skutečnost, že subjektivně-historický výklad je od textualismu metodologicky ze všech ostatních metod výkladu nejvzdálenější. Sleduje totiž i zcela neprávní prvky - historické, společenské, ekonomické, kulturní (...) souvislosti, kvưli kterým mohl mít zákonodárce takový úmysl, jaký opravdu měl. Vysvětlení poskytované důvodovou zprávou ukazuje

65 \2 odst. 2 zákona č. 89/2012 Sb., občanského zákoníku, ve znění pozdějších předpisů. Poslanecká sněmovna Parlamentu Ceské republiky [online]. [cit. 21. 03. 2020]. Dostupné z: https://www.psp.cz/sqw/ sbirka.sqw? $\mathrm{r}=2012 \& \mathrm{cz}=89$

66 Jak kupř́kladu upozorňuje MALANÍK, Michal. Explanatory Reports as a Means to Understand the Legislator-court Dialogue. In: KLUSOŇOVÁ, MALANÍK, STACHOŇOVÁ, ŠKOP, 2017, op. cit., s. 76 a násl.

67 SCALIA, GARNER, op. cit., s. 31.

68 Důvodová zpráva (konsolidovaná verze). Nový občanský zákoník. Ministerstvo spravedlnosti [online]. 20132015, s. 33 [cit. 29. 8. 2020]. Dostupná z: https://obcanskyzakonik.justice.cz/images/pdf/Duvodovazprava-NOZkonsolidovana-verze.pdf

Na tomto místě je také důležité upozornit, že článek operuje s konsolidovanou verzí důvodové zprávy, což je poměrně netypický druh dokumentu. Byt' se v diskutovaných záležitostech konsolidovaná verze s původní verzí (viz vládní návrh na vydání zákona občanský zákoník. Dostupný jako součást sněmovního tisku 362. Poslanecká snémovna Parlamentu Ceské republiky [online]. [cit. 27. 4. 2021]. Dostupné z: https:// www.psp.cz/sqw/text/tiskt.sqw?O $=6 \& C T=362 \& C T 1=0)$ významově neliší, lze vznést dotaz, zda konsolidovaná verze důvodové zprávy má stále ještě vypovídací hodnotu charakteristickou pro důvodové zprávy, nebo již hraniční s komentářovou literaturou. V tomto ohledu se sluší připomenout výše zmiňované snahy o ovlivnění následných interpretací (viz poznámka pod čarou č. 41), které jsou u konsolidované verze důvodové zprávy ještě žretelnější. 
spíše na výše uvedenou Scaliovu myšlenku o př́pustném významu textu. Pokud bychom následovali tuto myšlenkovou linii, dostali bychom se k závěru, že textualismus má přednost před textualismem. To jistě zákonodárce rríci nechce. V jeho pojetí je třeba pátrat po smyslu zákonných ustanovení a nelpět pouze na textu. ${ }^{69}$

Dostáváme se tedy k problému, že důvodová zpráva, která má (alespoň v tomto konkrétním prrípadě) napomoci adresátům právního předpisu vyhnout se potřebě konzultovat teoretické právnické publikace, sama nezvládá práci s teorií. Dokonce i u tak zásadního právního předpisu, jako je občanský zákoník, lze identifikovat značné nesrovnalosti. Přitom bylo možné očekávat, že si tvưrci dali práci s dostatečně důsledným odůvodněním, které jednoznačným způsobem vysvětluje, jaký je úmysl zákonodárce. Jen těžko lze odhadovat jeho úspěšnost a kvalitu ostatních důvodových zpráv.

\section{Předběžná šetření - potřeba dalšího zkoumání}

Významnou hodnotou tohoto článku je dále zejména prezentace výsledků výše odkazovaného empirického výzkumu. $V$ jeho rámci se participanti/participantky měli možnost vyjadřovat i k otázkám právní teorie, intepretace práva, a důvodových zpráv, se kterými legislativci operují.

Kupř́kladu Participantka č. 13 v rámci předběžného šetření uvedla, že je třeba teorii zmínit v důvodové zprávě, aby bylo o co se později opřít, a ,aby to každý pochopil“. Participantka č. 6, že nahlíží na důvodové zprávy jako na zdroj informací o tom, ,co tím chtěl básník ríci“. Participantka č. $7 \mathrm{k}$ tomu pak dodává:

„Proto se pake využivá diovodová zpráva. Clověk napiše nèco a do diovodové zprávy se více rozepišse ve stylu, takble jsme to mysleli, takhle to prosim interpretujte:"

Obdobně i Participant č. 12 vyjadřuje:

„I v rámci dìvodové zprávy si musi sepsat a zdìvodnit a vysvětlit, kede, proč a jak má být aplikován." Psaní právního předpisu lze označit za značně specializovanou právní disciplínu. ${ }^{70}$ Pokud se, jak naznačují zjištění z našeho předběžného šetření mezi legislativci, skutečně důvodové zprávy píši až v závěrečné fázi návrhu normativního textu, pak působí nesrovnalosti mezi paragrafovým zněním a textem důvodové zprávy o to více znepokojivým dojmem. Kupř́íkladu Participant č. 12 k tomuto uvádí:

„Když vytváríme paragrafové znèní, tak bych doporučoval, aby dưvodová zpráva byla vytvárena opravdu ažv závérečné fázi, kdy je na úrovni toho prvotního tvirrce již hotov text paragrafovébo znèní, jelikožphisky jsou velmi tekuté již v této fázi, a neni moc smysluplnépsát dìvodovou zprávu, když se permanentnè mèni to paragrafové znèni."

69 Důvodová zpráva v tomto bodě užívá formulace ,jen smysl holých slov“, což vysvětlování pouze znepřehledňuje. Ibid., s. 33.

70 ALBANESI, Enrico. Parliamentary Scrutiny of the Quality of Legislation within Europe. Statute Law Review [online]. 2020, s. 1-22, s. 8 [cit. 7. 10. 2020]. DOI http://doi.org/10.1093/slr/hmaa001 
Kvalitu důvodové zprávy může samozřejmě ovlivnit i čas, který mají legislativci na její zpracování. K tomu uvádí Participant č. 11 následující:

„Můře být ovlivnèna kvalita materiálu politickými rozhodnutím toho ministra-pokud on rekene, at' to udělají, ale chce to už za týden, tak ta kevalita toho legislativního materiálu klesá. Ted' nemyslim primo toho paragrafovébo textu, ale treba té divvodové zprávy, hodnoceni dopadu regulace apod. Ti lidé tam pak prijjdou a reknou, že na to méli týden, nemižete od nás čekat zázraky, ministr to chtél ted." Takové roz̧odnutí mữou a mají vliv na kvalitu toho materiálu."

$\mathrm{Na}$ tomto místě je vhodné upozornit na další dílčí zjištění, které koresponduje s rozdělením legislativců, které je uváděno v rámci kapitoly č. 7 výše odkazované monografie $^{71}$, kdy Participant č. 1 uvádí, že zpracování paragrafového znění normativního textu a doprovodných materiálů, mezi které důvodová zpráva patří, také může být rozděleno mezi jednotlivé legislativce:

„[...] je to o spolupráci toho vécnébo gestora a legislativce, tak tomu legislativci ani v této souvislosti nezbývá moc práce, protože zejména ty di̛vodové zprávy by měl zpracovávat vècný gestor."

Ke zjištěním, která se jistě mohou řadit také do kategorie těch znepokojivějších, se dále dá podřadit vyjádření Participanta č. 10, který $\mathrm{k}$ důležitosti a charakteru důvodových zpráv dále uvádí:

„Cím dál více ta dĩvodová zpráva je fantastickým výkladovým zdrojem, ta teleologie se dostává do popredí, možná má daleko vétš́ význam než význam jazykový. Ta [legislativní rada vlády] někedy i doporučí, at' daji legislativci nèco do té dìvodovky, at'je vidèt, o co jim jde. V pruibèhu toho projednáváni nékedo nazná, že by ta formulace mèla vypadat trochu jinak, aby se dosáblo toho cíle, pokud se toho cíle chce dosábnout. Nèkedy samožrejmè začnete vétrìt, že tam jsou zakamuflované [jiné] cíle."

Je tedy zřejmé, že stejně jako může důvodová zpráva sloužit k objasnění cílů zákonodárce, může stejně době sloužit i k zahalení skutečných záměrů a prezentaci těch, které jsou společensky více přijatelné. Poté se zdají být výše uvedené textualistické obavy a restrikce vůči důvodovým zprávám opět o něco více namístě. Na druhou stranu lze připomenout, že jako materiál legislativní historie, který postrádá normativní povahu, důvodové zprávy nejsou pro interpreta nikterak závazné. V tomto duchu se vyjadřuje i Participantka č. 8:

„Na drubou stranu, dìvodová zpráva neni závazná. Když se piše kvalitné, což my dèláme, máme takový pokyn i od vedeni, takeže se pišsou dloubé a dikkladné a konkrétni, a opravdu se tam snažíme vise vysvètlit. Ne jako když se člověk podivá na občana a na ZOK, když se prījímaly, kde je k. pèti paragrafüm jeden odstaveček. My miváme třeba A4 nebo i dvě k.jednomu paragrafu."

Jak tvrdí Aharon Barak, „nenípochyb o tom, že by soudci méli zuážit legislativní historii. Otázłoon je, jak vyvážit potrebu osvobozeni od minulosti s potrebou poučit se z. ni. " ${ }^{\text {"72 }} \mathrm{Na}$ výše uvedeném

71 Tedy 1) legislativce, kteří se aktivně podílejí na tvorbě normativního textu tím, že jej píší; 2) legislativce, kteři se podílejí na věcné agendě; 3) osoby, které již nevykonávají práci legislativce jako svou hlavní náplň práce, ale také se podílí na tvorbě normativních textů - kuprríkladu osoby, které normativní text pouze připomínkují. ŠKOP, MALANÍK, SMEJKALOVÁ, ŠTĚPÁNÍKOVÁ, VACKOVÁ, 2019, op. cit., s. 158-159.

72 BARAK, Aharon. Purposive Interpretation in Law. Princeton and Oxford: Princeton University Press. 2005 , s. 344. 
prríkladu občanského zákoníku a jeho důvodové zprávy lze pozorovat, že oba záměry mohou být do značné míry dosaženy ve stejném čase.

Tuto část úvah o důvodových zprávách, jejich smyslu, charakteru, a možném využití lze tedy uzavřít tím, že se nám v rámci předběžných šetření podařilo ukázat, jakým způsobem na důvodové zprávy pohlížejí legislativci, kteří se zúčastnili našeho předběžného šetření, a že obecně je považují za stěžejní doprovodný materiál navrhovaného normativního textu. Také předběžná šetření poukazují na potenciálně bohatý zdroj informací, kterým důvodové zprávy mohou být. Jestli tomu tak však skutečně je, bude teprve předmětem dalšího empirického zjišt'ování.

\section{Důvodová zpráva jako zdroj informací o kontextu}

Diskuse o postavení důvodových zpráv v kontextu hledání úmyslu zákonodárce stále není uzavřená. Ani tento článek si nečiní ambice nabídnout jednoznačné určení, nebot' by bylo nutně odsouzeno $\mathrm{k}$ vadnosti, a navíc by se nejednalo o řešení pragmatické ${ }^{73}$. V současné době není možné označit žádnou akademickou teorii interpretace práva za zcela dominantnî ${ }^{74}$ a ohledně pojmu legislativní historie, potažmo důvodových zpráv, je odborných textů $\mathrm{v}$ tuzemsku až překvapivě málo. ${ }^{75} \mathrm{Na}$ základě výše uvedeného lze však označit důvodové zprávy za kvalifikovaný zdroj informací ohledně existence a podoby konkrétních úmyslů zákonodárce, přestože se jedná o zdroj bez normativní hodnoty. ${ }^{76} \mathrm{~S}$ přihlédnutím k průběhu legislativního procesu jde o zdroj mnohdy nepřesný. ${ }^{77}$ Pro soudce však může jít v intencionalistickém pojetí o důležité vodítko.

73 Viz kuprríkladu ESKRIDGE, 1990, op. cit., s. 440.

74 Což způsobuje, že i užití, či neužití důvodových zpráv je interpretovou volbou. K tomu viz dále VERMEULE, Adrian. Judging under Uncertainty: An Institutional Theory of Legal Interpretation. Harvard University Press. Cambridge, London, 2006, s. 66.

75 Lze však upozornit na skutečnost, že zatímco v zahraniční literatuře je tematicky laděných odborných textů daleko více, lze dospět k obdobnému závěru - tedy, že neexistuje dominantní teorie ohledně diskuse o legislativní historii. Viz kupř́ikladu ESKRIDGE, 1990, op. cit., s. 367.

76 Tu má pouze samotný text právního předpisu. Viz obdobně ESKRIDGE, 1990, op. cit., s. 372.

77 Stojí zde za připomenutí, že úmysl zákonodárce vyjádřený v rámci důvodové zprávy nemusí (ani nemůže) reflektovat pozdější změny, které jsou do návrhu právního předpisu zapracovány na půdě Poslanecké sněmovny prostřednictvím pozměňovacích návrhů, nebo novelizačních předpisů. To v konečném důsledku může znamenat, že důvodová zpráva pro výklad konkrétního ustanovení nemusí být vủbec relevantní. Jako př́klad může sloužit \2 návrhu zákona o registru smluv a jeho důvodové zprávy. Poslanecká sněmovna Parlamentu Ceské republiky [online]. [cit. 27.4.2021]. Dostupné z: https://www.psp.cz/sqw/text/ tiskt.sqw?o=7\&ct=42\&ct1=0; a výsledné znění \ 8 odst. 2 zákona č. 340/2015 Sb., o zvláštních podmínkách účinnosti některých smluv, uveřejňování těchto smluv a o registru smluv (zákon o registru smluv), ve znění účinném k 14. 12. 2015. Dostupné z: https://www.zakonyprolidi.cz/cs/2015-340/ zneni-0 [cit. 27.4.2021]; Zatímco návrh zákona (a důvodová zpráva) hovoří o podmínce zveřejňovat písemné smlouvy, samotný právní předpis stanoví, že zveřejňované smlouvy musí být uzavřeny písemně (což má zcela jiné konsekvence a důvodová zpráva je nikterak nevysvětluje). V takových př́padech je pak vypovídací hodnota důvodové zprávy o úmyslu zákonodárce naprosto mizivá. 
Textualistickou obavou však stále zůstává, že v př́padě, že se soudce rozhodne manipulovat s textem právního předpisu, úmysl zákonodárce mu pro to může poskytnout dostatečný prostor. ${ }^{78}$ Snaha o objektivní interpretaci právního předpisu v kontextu hledání úmyslu jeho tvůrce se může stát půdou pro maskování vlastních tendencí či předsudkư ${ }^{79}$, ke kterým jsou samozřejmě náchylní i soudci. ${ }^{80}$ Objevují se i tvrzení, že soudci mezi možnými interpretačními doktrínami nevolí - pouze rozhodují př́pady. ${ }^{81}$ Těm však lze kontrovat, i s podporou empirických šetření, že přinejmenším někteří soudci o těchto teoriích v rámci své práce uvažuji. ${ }^{82}$

Lze se setkat s názorem, že soudci minimalizují šanci na učinění chyby, pokud legislativní historii nepoužiji1. ${ }^{83}$ Pokud ji nepoužijí, riskují, že jejich rozhodnutí budou s neurčitou frekvencí nesprávná. Pokud však legislativní historii budou konzultovat, riskují, že jejich rozhodnutí budou s neurčitou frekvencí nesprávná, a navíc že budou jejich rozhodnutí nákladnější. ${ }^{84}$ Navíc není záruka toho, že při pátrání v legislativní historii se interpret dozví něco o nejfrekventovanějším úmyslu zákonodárců, účelu právního předpisu, obvyklém užití použitých termínů ${ }^{85}$; případně zda se dozví něco vưbec o některém z těchto konceptů. Z hermeneutického hlediska se však jedná o nezanedbatelnou část rozhovoru, kterým právní interpretace je. ${ }^{86}$

Pokud se pak legislativec snaží skrze důvodovou zprávu komunikovat s interpretem ve výše naznačeném (a empiricky zjištěném) smyslu, pak lze důvodovou zprávu hodnotit

78 Kupř́ikladu Robert French přirovnává interpretaci ke kvantovému systému - množství možností a podob závisející na pohledu a použitém nástroji zkoumání. Pozorování/interpretace v tomto kontextu nezjišt'uje stav zkoumaného, ale určuje jej. FRENCH, 2019, op. cit., s. 44.

$79 \mathrm{~K}$ tomu kupř́íkladu poutavá analýza z prostředí USA in COLLINS, Ronald K. L. a David M. SKOVER. The Judge. 26 Machiavellian Lessons. Oxford University Press. New York, 2017, s. 70-75.

80 Kuprŕḱladu viz VERMEULE, 2006, op. cit., s. 155.

81 Kuprríkladu viz VERMEULE, 2006, op. cit., s. 157.

82 Jak ukazují kupříkladu výsledky pilotního šetření mezi soudci Nejvyššího soudu. Viz MALANÍK, Michal. Empirický výżkum metodologie interpretace práva. Disertační práce. Brno:Masarykova univerzita, Právnická fakulta, 2019, s. 110-111. Vedoucí práce Martin Škop. Dostupné z: https://is.muni.cz/th/hg64v/ [cit. 13. 1. 2021].

83 VERMEULE, 2006, op. cit., s. 190.

84 Ibid., s. 194. Zahraniční empirická šetření ukazují, že kvalitně provedenou legislativní historii (což lze vztáhnout i na důvodové zprávy) lze označit též za poměrně nákladný zdroj informací. A to jak na úrovni tvorby, tak na úrovni jejího zkoumání. Viz Ibid., s. 193.

85 Ibid., s. 190.

86 ESKRIDGE, 1990, op. cit., s. 438; K tomu dále výše odkazované zdroje pojednávající o rozhovoru zákonodárce-soud.

Dá se však opět kontrovat, že namísto konverzačního modelu právní interpretace, který upřednostňuje úmysl zákonodárce, by měl být užíván konstruktivní model, který se soustředí na to, aby objekt interpretace (text) učinila co možná nejlepším. K tomu viz kupř́lkladu VOGENAUER, Stefan. What is the Proper Role of Legislative Intention in Judicial Interpretation? Statute Law Review [online]. 1997, roč. 18, č. 3, s. 240 [cit. 7. 10. 2020]. Dostupné z: https://academic.oup.com/slr/ article-abstract/18/3/235/1643945? redirectedFrom=fulltext 
jako materiál poskytující spolehlivé vysvětlení a zdůvodnění konkrétní volby v normativním textu užitých slov, které se jinak mohou zdát nesmyslné, nebo jinak nekorespondující s obecným účelem dané právní úpravy. ${ }^{87} \mathrm{I}$ tato komunikace je ale uzamčená v čase. Úmysl zákonodárce $\mathrm{v}$ kontextu průběhu existence konkrétního normativního textu zaslouží čím dál méně pozornosti ${ }^{88}$, nebot’ zatímco úmysl tvůrce v čase stagnuje, normativní text má být schopen reagovat i na situace nezamýšlené. ${ }^{89}$

I na tomto místě je však zapotřebí připomenout, že ani tyto pokusy o komunikaci nelze brát jako autoritativně určený způsob budoucí aplikace právního předpisu. Pokud by tomu tak bylo, museli bychom dále řešit další ovlivňující faktory a možná nebezpečí. $\mathrm{V}$ prípadě, že by se nenormativním textem důvodových zpráv ze strany moci zákonodárné dala určovat činnost moci soudní, pak by přicházely do úvahy další konsekvence ohledně lobby, manipulování s obsahem důvodových zpráv ${ }^{90}$, a další záležitosti v konečném důsledku problematické z hlediska nezávislosti soudní moci. Tyto obavy se nicméně podepisují na textualistických závěrech, že by se důvodové zprávy neměly používat ani v prrípadě nejasností. ${ }^{91}$

Kategorické odmítnutí použití důvodových zpráv však i přes výše uvedené námitky př́iliš nedává smysl. ${ }^{92}$ Textu nemůže být zcela porozuměno bez kontextu. ${ }^{93} \mathrm{Na}$ předchozí větě se shodne přinejmenším většina i jinak protichůdně zaměřených interpretačních teorií. Neshoda panuje na tom, co daný kontext může tvořit a kde po něm pátrat. ${ }^{94}$ Právě kontext mohou důvodové zprávy mnohdy poskytnout, což může dopomoci k vyplnění

87 Viz COX, 1947, op. cit., s. 382.

88 Jak upozorňuje kuprŕíkladu VOGENAUER, 1997, op. cit., s. 243.

89 Obdobně kupř́ikladu SCALIA, GARNER, 2012, op. cit., s. xxv, 16; Také se k tomuto argumentu dá vztáhnout známá teze Gustava Radbrucha, že zákon může (a musí být) moudřejší než jeho autor. Viz RADBRUCH, Gustav. Rechtsphilosophie II. Upravil Arthur Kaufmann. 2. vyd. Heidelberg: C.F. Müller Juristischer Verlag. 1993, s. 345. Dostupné kuprŕikladu z: https://books.google.cz/books?id= hZA9XFtmEYkC\&lpg=PA345\&ots=-vBkps6ByB\&dq=das $\% 20$ Gesetz $\% 20 \mathrm{kann} \% 20 \mathrm{kl} \% \mathrm{C} 3 \% \mathrm{~B}-$ Cger $\% 20$ sein $\% 20$ als $\% 20$ seine $\% 20$ Verfasser $\% 20 \%$ E2\%80\%93\%20es $\% 20$ muss $\% 20$ sogar $\% 20 \mathrm{kl} \%$ -

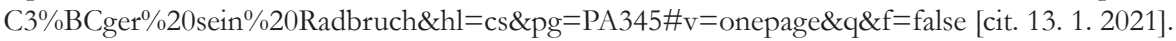

90 Obdobně hovoří též kupř́kladu KAVANAGH, Aileen. Original intention, enacted text, and constitutional interpretation. The American Journal of Jurisprudence [online]. 2002, roč. 47, č. 1, s. 255-298, s. 279 [cit. 27. 12. 2020]. DOI https://doi.org/10.1093/ajj/47.1.255

K otázce lobbování legislativců viz kupříkladu ŠKOP, MALANÍK, SMEJKALOVÁ, ŠTĚPÁNÍKOVÁ, VACKOVÁ, 2019, s. 170.

91 Viz kupř́ikladu VERMEULE, 2006, op. cit., s. 184.

92 Obdobně uvažuje kupř́kladu EASTERBROOK, Frank H. What Does Legislative History Tell Us? Chicago-Kent Law Review [online]. 1990, roč. 66, č. 2, s. 444 [cit. 13. 1. 2020]. Dostupné z: https://chicagounbound.uchicago.edu/cgi/viewcontent.cgi?article=2141\&context=journal_articles

93 Viz McGREAL, Paul E. A constitutional defense of legislative history. William \& Mary Bill of Rights Journal, 2005, roč. 13, č. 4, s. 1299. Dostupné z: HeinOnline [právní informační systém]. [cit. 27. 12. 2020].

$94 \mathrm{~K}$ tomu dále kuprríkladu EKINS, Richard. Interpretive Choice in Statutory Interpretation. The American Journal of Jurisprudence [online]. 2014, roč. 59, č. 1, s. 21-24 [cit. 7. 10. 2020]. Dostupné z: https://doi. org/10.1093/ajj/auu008 
př́padné interpretační prázdnoty. ${ }^{95}$ Textualistické představy o tom, že materiály legislativní historie se nedají použít, nebot' normativní hodnotu má pouze text ${ }^{96}$, a tedy veškerý $\mathrm{k}$ interpretaci potřebný kontext lze vyvodit př́mo z něj, jsou uplatnitelné pouze při splnění následujícího předpokladu. Tímto předpokladem je, že legislativci pečlivě rozmýšlí, jak text, který písí, bude chápán, a odpovídajícím způsobem opatrně volí slova, která v něm použijí. ${ }^{97}$ Tento apel na legislativce samozřejmě míři i od intencionalistů - bez kvalitního vypracování důvodové zprávy z ní lze o úmyslu zákonodárce zjistit jen velmi málo, pokud vůbec něco. $V$ takovém případě ji lze označit za stejně nejasný zdroj, jako samotný text interpretovaného ustanovení právního předpisu. ${ }^{98}$ Jak ale vyplývá z výše uvedených empirických zjištění, ne vždy mají legislativci dostatek času být takto precizní. Také, jak ukázal výše zmíněný př́klad interpretačích instrukcí občanského zákoníku, i v př́padě relativně dlouhého časového rámce, jsou myslitelné př́pady, kdy tyto snahy o preciznost selžou. Za takové situace je poté zkoumání důvodových zpráv, at' už analýzou jejich textu či obsahovou analýzou, pro doplnění informací o kontextu interpretovaného textu smysluplné.

\section{Závěr}

Tento článek se věnoval důvodovým zprávám, konkrétní části materiálů legislativní historie, v provázanosti s konceptem úmyslu zákonodárce. Připomenul, že zatímco důvodové zprávy mají svůj právní rámec a mělo by být žrejmé, kdy jsou tvořeny a co je jejich obsahem, v praxi tomu tak nutně být nemusí. Ukázal také, že s konceptem úmyslu zákonodárce pracuje také občanský zákoník. V jeho pojetí však panuje mnohem měnší míra pochopení toho, co to vlastně úmysl zákonodárce je (jestli vưbec existuje), jaké mưže mít podoby či kde a jak jej zkoumat - pokud je to tedy vůbec účelné.

Článek proto upozornil na základní diskutované problematické body úmyslu zákonodárce. Zdůraznil, že ignorovat jeho existenci nedává v dnešní době smysl, nebot' i u zákonodárce - kolektivního orgánu tvořeného větším množstvím jednotlivců, lze úmysl identifikovat, a to kupř́kladu jako společný sdílený plán. Neopomněl však ani zmínit množství protichůdných názorů, tvrdících, že u kolektivního orgánu konkrétní úmysl vysledovat nelze, a i kdyby, postrádá normativní hodnotu. Těm se však dá s úspěchem kontrovat, že normativní hodnota není jedinou kvalitou, kterou úmysl zákonodárce nese.

95 Viz kupř́lkladu McGREAL, 2005, op. cit., s. 1299.

96 Což lze vyvodit i z představy, že zákonodárci hlasují pouze o textu, nikoli o materiálech legislativní historie. Viz BELL, 1999, op. cit., s. 48.

97 K tomu kuprŕḱladu EKINS, 2012, op. cit., s. 274.

98 Viz kupř́kladu HORACK, 1932, op. cit., s. 129; Obdobně též Lord LISVANE. Why Is There So Much Bad Legislation? Statute Law Review [online]. 2020, roč. 41, č. 3, s. 291-303, s. 301 [cit. 7. 10. 2020]. DOI https://doi.org/10.1093/slr/hmz019 
V kontextu teoretické literatury, omezeného počtu právních předpisů a judikatury, článek připomenul, že důvodové zprávy jsou podpůrný materiál, který (nejen) v našem právním prostředí normativní hodnotou neoplývá. Diskutoval však, že může být užit jako zdroj informací jak ohledně tvorby právního textu, tak i ohledně zamýšleného smyslu či dokonce zamýšlené aplikace daného právního textu. Přes absenci hodnoty normativní lze v důvodových zprávách spatřovat hodnotu pravdivostní - tedy lze na ně pohlížet jako na důkaz týkající se kontextu právního textu.

Hodnota tohoto článku však nespočívá pouze v diskutování teorií týkajících se důvodových zpráv a úmyslu zákonodárce. Poskytuje též konkrétních př́iklady z našeho právního prostředí, kde se uplatnily odlišné př́stupy k jejich úloze a použití. Dále, a to zejména, článek představil empirická zjištění z výzkumu prováděného mezi tuzemskými legislativci, která alespoň v základu objasňují, jaké zkušenosti existují s prací s důvodovými zprávami na úrovni jejich tvorby. Z těchto zjištění lze jednak vyvodit další související úvahy o konceptu úmyslu zákonodárce, ale i o potřebách dalšího zkoumání. S přihlédnutím k úvahám legislativců o důvodových zprávách jako prostředku komunikace mezi nimi a právními interprety je podstatné i zjištění, že zahraniční koncept rozhovoru zákonodárce-soud je výzmnamný i v našem právním prostředí, přestože zatím absentuje větší př́padová studie objasňující jeho projevy.

Další výzkum, který je s ohledem na (velmi malé) množství podobně laděných empirických šetření pro další posun diskuse esenciální, by měl směřovat k upevnění metodologických cest, jakými jsou důvodové zprávy zkoumány, a to zejména v procesu právní interpretace. Je totiž kupř́kladu třeba ožrejmit, $\mathrm{k}$ jak rozdílným výsledkům se interpret může dobrat, pokud bude analyzovat text důvodové zprávy oproti případu, kdy bude využívat obsahovou analýzu důvodových zpráv. V současné době lze totiž vysledovat značnou nahodilost $\mathrm{v}$ postupu práce s těmito materiály, což formalistickou důvěru v jejich používání prríliš neupevňuje. Není pak totiž zřejmé, jakým způsobem bylo výsledku dosaženo, což nahrává odsuzování pátrání po úmyslu zákonodárce jako př́liš subjektivistické variantě. Informace o kontextu interpretovaného právního textu, který lze z důvodových zpráv mnohdy extrahovat, však může být pro správné posouzení stěžejní. 